\title{
World Assumptions and Youth Identity as Predictors of Social Activity Preferences
}

\author{
Rail M. Shamionov ${ }^{a^{*}}$, Marina V. Grigoryeva ${ }^{a}$, Anton V. Grigoryev ${ }^{a}$ \\ a Saratov State University, Saratov, Russia \\ *Corresponding author. E-mail: shamionov@mail.ru
}

Background. The social activity of young people is the driving force behind socio-economic and socio-political processes in society. It is due to their social activity that positive changes are taking place in different spheres of life.

Objective. We set out to analyze the preferences and predictors of the directions of young people's social activity.

Design. Our study involved 251 people from the Saratov region, Russia, of median age (M) 20.11, SD = 1.2 (41\% male). To measure their basic assumptions, we used the Janoff-Bulmann World Assumptions Scale (WAS); their identity characteristics were measured with the Kuhn and McPartland Twenty Statements Test (TST) "Who am I?". To evaluate their social behavior preferences, we used 11 unique proprietary scales which we developed on the basis of a pilot study with relevant theoretical validity.

Results. Our study found that youth preferences for various forms of social activity can be divided into two main clusters: organizational-social and individual-personal. Our results revealed that individual-personal activity had a more complex structure, with well-expressed intensity, than the organizational-social form of social activity Young people's assumptions most strongly condition variations in their preferences for educational-developmental, socio-political, recreational-cognitive, and self-developmentrelated spheres of activity. The most influential predictors of social activity in young people are their assumptions regarding their own significance, their ability to manage events, and their luckiness. We established that an individual's basic beliefs do not influence variations in their preferences for mass cultural, religious, creative, and informal activities in a group. Young people's sense of identity influences variations in their preferred types of social activity. The most influential predictors of social activity preferences were negative personal, personal, and family-related identities. Preferences for social activity are less influenced by gender, religious, and ethnic identity, as well as by identity based on activity and appearance.

Conclusion. We present some conclusions regarding the strong determination of the first cluster (political, religious and voluntary types of activity) by identity, and the second cluster (ranging from educational to recreational cognitive activity) by assumptions about the world.
Keywords: social activity; world assumptions; identity; young people 


\section{Introduction}

Numerous studies of young people's social activity have covered various aspects of this phenomenon, including civic, political, voluntary, and cyber activity. However, there is a clear deficit of empirical studies on the changing preferences of young people for certain forms of activity, their intensity, the psychological characteristics of their activity, and its determinants.

The phenomenon of personal social activity has two most important dimensions: the socio-economic and the socio-psychological (Shamionov, 2012; Shamionov \& Grigoryeva, 2012; Grigoryeva, 2018). The first dimension is connected with the social development of the country, the influence young people have on political and economic changes, and their innovativeness and constructiveness/destructiveness. The second dimension, which is undoubtedly related to the first, presents the possibilities for understanding the causes, dynamics, mechanisms, and determinants of social activity as a scientifically cognizable phenomenon and a specific subject of social psychology.

The understanding of this phenomenon will allow the creation of programs of "directed" personal socialization, demonstration of innovative values, and openness to changes that create the social and psychological conditions for the development of society. The most important factor dictating the relevance of studying the psychological determinants of individual social activity in countries with developing democracies, is the need to encourage active civic participation by young people, including their innovativeness and creativity. Thus we studied young people's social activity via its various aspects, i.e. psychological mechanisms, educational initiatives, social and political effects, etc. For this reason T.G. Kiseljova (2014) views youth social activity through the prism of social giftedness, while S.S. Kudinov (2014) defines it via the concept of personal fulfillment.

We defined social activity as the planning, organization, and realization of behavior in the social environment regulated by internal (motivation, beliefs, values, identity) and external (requirements of the social environment) determinants. Personal and group social activity presupposes not only participation in public life, but, above all, an initiative and creative attitude toward social activity, an attitude which is itself a subject of social life. This is the realization of a person's attitude to the surrounding reality. It is determined by the individual's needs-related and motivational spheres, related to the person's qualities, realized in the process of social interactions, and aimed at self-change and transformation of reality in accordance with a person's own needs and beliefs, and the demands of the social environment.

According to K.A. Abul'khanova-Slavskaya (1999), the necessary condition for constructive individual and group social activity is the ratio of initiative and responsibility, which are not necessarily opposed to each other. It is obvious that the interdependence of the direction of an individual's activity and initiative, together with his/her sense of responsibility, is an important factor in his/her pro-sociality.

Studies of young people's social activity have centered around the problems of their psychological and socio-psychological dependence. Scientists have been actively studying social activity in the following areas: 1) social networks (Sherman et al. (2018); Seigfried-Spellar and Lankford (2018); Savrasova-V’un (2017); 
Rjabikina \& Bogomolova (2015); Shhebetenko (2016); Krasilshhikov \& Osetrov (2017)); 2) the educational environment (Beljaeva \& Istratova, 2014; Skornjakova, 2015); 3) socially-transforming activity (Eremina, 2015), as an element of social self-definition (Akbarova, 2015) and socio-cultural activity (Sharkovskaja, 2016); 4) politically-active behavior and its orientation depending on political involvement and beliefs (Grant et al., 2017; Russo and Amna, 2016; Rozhkova, 2015); 5) impact of normative perceptions of aggression and empathy on cyberbullying (intimidation) (Ang et al., 2017) and other negative forms of activity in the cyberspace (Kalaitzaki and Wright, 2017); 6) volunteer activity involving the elderly (Svishheva, 2017); 7) specifics of its formation (Perminova, 2016); 8) comparative study of autonomous and external motivation (Hardy et al., 2015; Ferguson et al., 2015); and 9) sect-related social activity and its behavioral consequences (Merrilees et al., 2013).

Research shows that the use of social networks by young people can contribute to more active political and civic participation (Chan \& Guo, 2013). Social activity can be used as a tool for solving social problems (Sedova, 2015; Furman \& Gridina, 2015 ) and be a factor in personal socialization (Kondrateva, 2017; Rudneva, 2017). We analyzed personal (dark triad, sadism, five-factor model) factors of various types of social activity in social networks (from trolling to confession) (SeigfriedSpellar \& Lankford, 2018), as well as factors that interfere with young people getting involved in social activity (Miller, 2012); a number of studies over the last five years have been devoted to theoretical interpretation of this phenomenon (Shamionov, 2012; 2014; Balabanova, 2017; Sitarov \& Maralov, 2015) and to analysis of the determinants of social activity (Shamionov \& Grigoryeva, 2012; Perminova, 2016; Shhebetenko, 2016).

Recently, there have been many investigations aimed at analyzing the psychological effects of realized social behavior. In particular, these studies focused on its consequences for young people's responsibility and control function, as well as on the corresponding behavioral effects (Sherman et al., 2018); the influence of online activity, under conditions of information and messages posted on social networks, on young people's behavior under alcoholic intoxication (Pegg et al., 2018); and, finally, the influence of cyberactivity on youth political and civic activity (Chan \& Guo, 2013; Savrasova, 2017).

Studies of social activity (Shamionov \& Grigoryeva, 2012; Moiseev, 2013; Beljaeva \& Istratova, 2014; Kudinov, 2014) convincingly prove the realization of various types of young people's activity. That is why we need to view the social activity of young people as a multiple activity.

Based on our analysis, we can conclude that there are two predominant trends in the studies of social activity, i.e. analysis of the psychological factors leading to pro-social activity and its types, and analysis of the "resonant" forms of social activity, which are the forms that have "behavioral" effects. Scientists are actively studying issues related to social activity on the Internet and its impact on young people's civic and political behavior.

At the same time, there is an obvious lack of concrete scientific studies regarding the characteristics of social activity and its determinants under conditions of young people's multiple activity. The directions young people's social activity 
take are characterized by great diversity, and this has become a social risk factor (Shamionov \& Grigoryeva, 2012). Therefore, the study of characteristics and predictors of this phenomenon must be conducted with consideration of its polydirectionality.

Our study analyzed young people's basic beliefs and sense of identity as predictors of social activity. The concept of basic beliefs was created in connection with the study of psychological trauma and coping processes. In accordance with this concept, we singled out three basic assumptions: the assumption that there is more good than evil in the world; the assumption that the world is full of meaning; and the assumption regarding self-worth. Basic personal assumptions (aka world assumptions) undergo significant changes under the influence of personal psychological traumas and traumatic events, which result in the fundamental destruction of habitual views and patterns of behavior (Janoff-Bulman, 1989; 1992). Investigations of people's world assumptions have made it possible to establish their connection with traumatic events, and the potential shifts that can occur through a newly discovered sense of vulnerability (Janoff-Bulman, 1989).

Despite the application of this concept to the analysis of post-traumatic states, we believe that basic assumptions can cover a wider range of objects, including the analysis of young people's social activity. Obviously, basic assumptions are personal characteristics that regulate different types of activity, their direction, and intensity. Our previous research showed their connection with the socio-psychological adaptation of students in Russia (Shamionov et al., 2013). The study of young people's motivation related to volunteer activity in its relation to their world assumptions has shown that the motivation of volunteers in adolescence is more based on external factors (positive attitude of others, social significance, social contacts) than on the deep philosophical assumptions of the individual volunteer (Solobutina \& Nesterova, 2018). However, these assumptions start playing a more important role in adolescence (Shamionov, 2017). We have discovered a bias toward social activity depending on a belief in a just world (BJW) (Maes et al., 2012). Earlier, we discovered a feedback factor as well, i.e. the influence of a person's life events on the establishment of his/her world assumptions (Catlin \& Epstein, 1992).

Personal and social identity are studied from the point of view of their influence on social behavior (Shamionov \& Grigoryeva, 2012; Merrilees et al., 2013). The importance of identity for regulation of social activity in different communities is related to the fact that characteristics of identity are formed in interpersonal relationships and social activity, and influence these relationships and activity.

\section{Methods}

The purpose of this study is to research world assumptions and social identity as predictors of social activity. The study's object is social activity, and its subject is world assumptions and identity as the determinants of the direction taken by students' activity. We assumed that 1) certain types of social activity may be grouped together based on their manifestation for an individual, and 2) that there are similarities and differences in the determination of young people's preferred areas of social activity. 


\section{Participants}

Our sample consisted of 251 students in the Saratov region, Russia, median age (M) 20.11 (17 to 23 years), $S D=1.2$ (41\% male). The sample was formed by simple randomized selection. It should be noted that the vast majority (more than 90\%) of young people aged 17 to 23 years are students at universities and colleges (Federal, 2018).

\section{Procedure}

To measure basic assumptions, we used the Janoff-Bulman's World Assumptions Scale (WAS) (Janoff-Bulman, 1989). The version we used had been created by O.A. Kravcova, based on the results of the scale's adaptation for Russian speakers by Kravcova (2000), Padun and Kotelnikova (2012), and an additional reliability and internal consistency test. This version of the WAS contained 32 items divided into eight subscales: 1) benevolence of the world (BW);2) benevolence of people (BP); 3) justice (J); 4) control (C); 5) randomness as a principle of distribution for the occurring events (R) [ $\mathrm{R}^{\star}$ regressive scale]; 6) self-worth (SW); 7) self-control, control over events (SC); and 8) luckiness (L). These were distributed among three basic scales: 1) an assumption that there is more good than evil in the world; 2) an assumption that the world is full of meaning; and 3) an assumption regarding self-worth. All scales have undergone reliability checks: Cronbach's $\alpha=0.65-0.66$; Friedman's $\chi 2=176.8$, with $\mathrm{p}<0.001$.

The students' sense of identity was measured by the Kuhn-McPartland 20 Statements Test (the "Who am I?" test). As a result, we singled out various categories. Each identification category was assigned to a certain type after being tested by three experts with PhDs in social psychology.

The students' preferences in social activity and their general self-assessment of social activity were identified using specially designed scales defined on the basis on a pilot research project. The pilot study involved 80 students from Saratov State University aged 18 to 23 years. They were asked to identify social activity and define its main characteristics and directions. Based on these results, we developed a scale of 11 types of social activity. Then, five qualified psychology experts evaluated the scale for its compliance with the identified forms of social activity, and the most frequently mentioned areas of social activity were selected. Among them were: 1) recreational and cognitive social activity (group tourism) (RCSA); 2) self-development activity (training, etc.) (SDA); 3) educational and developmental activity (participation in educational initiatives) (EDA); 4) hobby and communicationrelated social activity (related to friends and acquaintances) (HCSA); 5) Internet and network-related activity (INA); 6) socio-political activity (SPA); 7) culture and mass social activity (CMSA);8) social activity in the spiritual and religious sphere (SASRS); 9) informal social activity in the collective (ISAC); 10) creative social activity (art studios, etc.) (CSA); 11) volunteer social activity (volunteering) (VSA); and 12) general (generalized) subjective assessment of social activity. All scales have undergone reliability checks: Cronbach's $\alpha=0.68-0.69$; Friedman's $\chi^{2}=964.1$, with $\mathrm{p}<0.001$.

The socio-demographic parameters were singled out with the help of the questionnaire compiled by the authors. 
The logic of the study was as follows. Initially, we analyzed how frequently each type of social activity was manifested; then we carried out cluster analysis to classify the activities into groups, and determine the predictors of the different forms of social activity based on regression analysis.

\section{Data analysis}

To reach our goal, we used primary statistics, cluster analysis (the intra-group relationships method), and regression analysis (direct step-by-step method). All statistical analyses were conducted with the aid of the Statistical Package for the Social Sciences (SPSS 22.0).

\section{Results}

Cluster analysis of the assessments of the young peoples' social activity forms made it possible to single out two large clusters (see Figure 1).

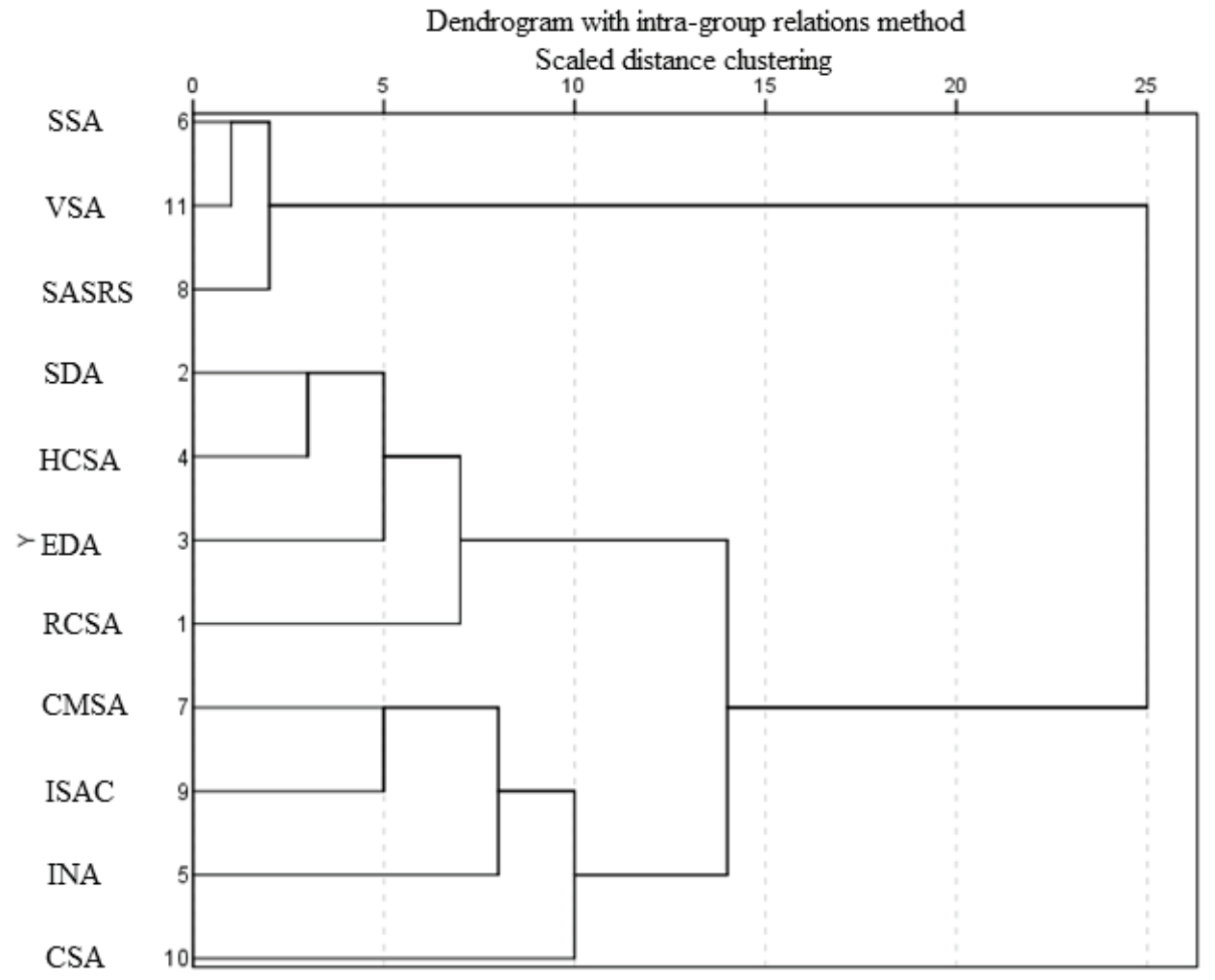

Figure 1. Preference clusters from the young people's social activity forms

The first cluster, which is structurally less complex, combines three forms of social activity: socio-political (SSAT), voluntary (VSA), and social activity in the spiritual and religious sphere (SASRS). These forms of social activity are to a great extent realized in public associations, and are related to more or less organized activities, and the existence of a formal group structure to which the individual 
belongs. Therefore, we defined this cluster as a "preference for organizational and social forms of social activity."

The second, more complex cluster combines eight forms of social activity: 1) activity in the sphere of self-development (SDA);2) hobbies and communication (HCSA); 3) education and development (EDA); 4) recreation and cognition (RCSA); 5) mass culture (CMSA); 6) informal activity in a work collective or educational group (ISAC); 7) Internet and network activity (INA); and 8) creative social activity (CSA). All these forms of social activity are to a great extent related to individual initiative and performance. Therefore, we defined this cluster as "preference for individual and personal forms of social activity."

We subdivided the cluster "preference for individual and personal forms of social activity" into two less complex sub-classes, which we named "preference for social activity for self-development" and "preference for social activity in entertainment." We further divided the first sub-class into "preference for social activity for personal development" and "preference for social activity for physical self-development." The second sub-cluster was divided into "preference for social activity in productive entertainment" and "preference for social activity in consumer entertainment."

\section{The Impact of World Assumptions}

Let us turn to the results of the regression analysis, where the form of social activity was chosen as a dependent variable and world assumptions as an independent one (Table 1).

Concerning basic personal beliefs, we found four predictors of students' preference for educational and development activity, two positive and two negative. The positive predictors were the assumption regarding the justice of the world $(\beta=0.341)$ and the assumption regarding one's self-worth $(\beta=0.299)$. The negative predictors were the assumption regarding one's luckiness $(\beta=-0.198)$ and the assumption regarding control of the world $(\beta=-0.141)$.

These results show that a belief in the justice of the world increases the preference for activity in the sphere of education and self-development. Such activity helps fulfill the desire to achieve, reduces anxiety, initiates interactions with other subjects of education, and promotes interactions without any fear of the negative effect associated with the unfair distribution of awards for one's efforts. The assumption regarding one's self-worth is a personal basis for students placing high importance on educational and developmental activity, since this activity increases confidence in one's own strengths and abilities, and obviously, forms positive affective interactions in the educational environment. On the other hand, belief in one's luckiness reduces students' internality, does not contribute to their efforts and organization of purposeful activity to achieve their learning goals, and provokes hope for a successful outcome in a situation without the student having to invest in learning the material. Belief in the world's controllability does not contribute to an increase in the students placing importance on educational and developmental activity.

A high level of anxiety, a desire to avoid trouble, an expectation of making mistakes, and putting an emphasis on them and ways to prevent them, determine 
Table 1

World Assumptions as Predictors of Social Activity

\begin{tabular}{|c|c|c|c|c|c|c|}
\hline \multirow[t]{2}{*}{$\begin{array}{c}\text { Form of social } \\
\text { activity }\end{array}$} & \multirow{2}{*}{$\begin{array}{l}\begin{array}{c}\text { World assump- } \\
\text { tions }\end{array} \\
\text { J justice }\end{array}$} & \multicolumn{2}{|c|}{$\begin{array}{l}\text { Non-standardized } \\
\text { coefficients }\end{array}$} & \multirow{2}{*}{$\begin{array}{c}\begin{array}{c}\text { Standardized } \\
\text { coefficients }\end{array} \\
0.341\end{array}$} & \multirow{2}{*}{$\begin{array}{c}\mathbf{t} \\
4.850\end{array}$} & \multirow{2}{*}{$\begin{array}{l}\mathbf{p} \\
0\end{array}$} \\
\hline & & 0.760 & 0.157 & & & \\
\hline \multirow{3}{*}{$\begin{array}{l}\text { Educational and } \\
\text { developmental }\end{array}$} & SW self-worth & 0.626 & 0.153 & 0.299 & 4.101 & 0 \\
\hline & L luckiness & -0.573 & 0.204 & -0.198 & -2.811 & 0.006 \\
\hline & $\begin{array}{l}\text { C control } \\
\text { of the world }\end{array}$ & -0.361 & 0.181 & -0.141 & -2.000 & 0.047 \\
\hline \multicolumn{7}{|c|}{$R^{2}=0.22 ; F=11.87 ; p<0.001$} \\
\hline $\begin{array}{l}\text { Hobbies and } \\
\text { communication }\end{array}$ & $\begin{array}{l}\text { SC degree of } \\
\text { self-control }\end{array}$ & 0.431 & 0.142 & 0.222 & 3.027 & 0.003 \\
\hline \multicolumn{7}{|c|}{$\mathrm{R}^{2}=0.05 ; \mathrm{F}=9.16, \mathrm{p}<0.01$} \\
\hline $\begin{array}{l}\text { Internet and } \\
\text { networks }\end{array}$ & $\mathrm{R}^{\star}$ randomness & -0.393 & 0.175 & -0.167 & -2.247 & 0.026 \\
\hline \multicolumn{7}{|c|}{$R^{2}=0.03 ; F=5.05, p<0.05$} \\
\hline \multirow{2}{*}{ Socio-political } & SW self-worth & -0.536 & 0.175 & -0.226 & -3.063 & 0.003 \\
\hline & $\mathrm{R}^{\star}$ randomness & 0.521 & 0.194 & 0.199 & 2.693 & 0.008 \\
\hline \multicolumn{7}{|c|}{$\mathrm{R}^{2}=0.8 ; \mathrm{F}=7.1, \mathrm{p}<0.01$} \\
\hline $\begin{array}{l}\text { Volunteering } \\
\text { and social }\end{array}$ & L luckiness & -0.464 & 0.183 & -0.188 & -2.538 & 0.012 \\
\hline \multicolumn{7}{|c|}{$\mathrm{R}^{2}=0.04 ; \mathrm{F}=6.44, \mathrm{p}<0.01$} \\
\hline \multirow{3}{*}{$\begin{array}{l}\text { In the sphere of } \\
\text { self-development }\end{array}$} & $\begin{array}{l}\text { SC degree of } \\
\text { self-control }\end{array}$ & 0.649 & 0.206 & 0.247 & 3.152 & 0.002 \\
\hline & C control & -0.521 & 0.192 & -0.215 & -2.708 & 0.007 \\
\hline & J justice & 0.356 & 0.155 & 0.169 & 2.292 & 0.023 \\
\hline \multicolumn{7}{|c|}{$\mathrm{R}^{2}=0.09 ; \mathrm{F}=5.73, \mathrm{p}<0.01$} \\
\hline \multirow{2}{*}{$\begin{array}{l}\text { Recreational } \\
\text { and cognitive }\end{array}$} & $\begin{array}{l}\text { BW benevolence } \\
\text { of the world }\end{array}$ & 0.717 & 0.176 & 0.288 & 4.062 & 0 \\
\hline & $\begin{array}{l}\text { SC degree of } \\
\text { self-control }\end{array}$ & 0.708 & 0.226 & 0.223 & 3.139 & 0.002 \\
\hline \multicolumn{7}{|c|}{$\mathrm{R}^{2}=0.12 ; \mathrm{F}=12.4, \mathrm{p}<0.001$} \\
\hline $\begin{array}{l}\text { Generalized } \\
\text { self-evaluation } \\
\text { of social activity }\end{array}$ & $\begin{array}{l}\text { SC (degree of } \\
\text { self-control) }\end{array}$ & 0.317 & 0.152 & 0.156 & 2.093 & 0.038 \\
\hline \multicolumn{7}{|c|}{$\mathrm{R}^{2}=0.02 ; \mathrm{F}=4.38, \mathrm{p}<0.05$} \\
\hline
\end{tabular}

Note. ${ }^{*}$ regressive scale 
students' activity in the educational environment, and change the students' orientation away from the achievement of educational goals, to trying to organize special conditions of activity that exclude the inevitability of erroneous actions.

A student's degree of self-control contributes to a preference for hobby-related and communicative activity $(\beta=0.222)$. Along with resilience, self-control allows young people to regulate their relationships with friends and acquaintances during leisure time and while engaging in informal communication, which makes this communication devoid of conflict and, in this connection, attractive. Feedback is also possible: the importance of hobby-related and communicative activity increases the actualization of such qualities as self-control, restriction of impulsive reactions, the ability to compromise, and so on.

The belief that there are a lot of uncertain, random, and uncontrollable events in the world contributes to the increase in student preferences for activity on the Internet $(\beta=-0.167)$, which may be due to the protected nature of the Internet and network-related activity, whereby poorly controlled virtual events do not lead to a negative result, and the responsibility for results is weaker than in real life.

An assumption that there is too much diversity and uncertainty in the world, and a belief in the significant role of random, uncontrollable events, taking into account the reversibility of the scale, reduces a youth's preference for social and political activity $(\beta=0.199)$. Self-worth also determines the decrease in preferences for various kinds of socio-political activity $(\beta=-0.226)$. This result shows that the assumption regarding diversity and dynamism of the world does not promote a preference for socio-political activity. As to why a high sense of self-worth decreases the preference for socio-political activity, it seems obvious that young people consider socio-political activity a type of activity that can only be viable in a political or social organization with a certain hierarchy of relations, where one's self-worth is difficult to maintain.

Belief in one's luckiness reduces the preference for volunteer social activity $(\beta=-0.188)$. The decrease in the preference for volunteer social activity due to belief in one's luck can be explained by the fact that the belief in what causes a successful outcome of a life situation extends not only to personal events, but also to events in other people's lives. Consequently, other people do not need their help, and the results of their life events depend on how lucky they are.

The predictors regarding preference for activity in the sphere of self-development includes two positive factors and one negative factor. Positive predictors include the belief in possibility of self-control $(\beta=0.247)$ and the belief in justice of the world $(\beta=0.169)$. The assumption regarding control of the world decreases young people's preference for activity in the sphere of self-development $(\beta=-0.215)$. It is obvious that the stronger young people's beliefs in a high degree of self-control, the sooner they will try to change something in themselves in accordance with conditions of their life or activity, and will try to improve their qualities, because they believe that their efforts will be justly rewarded. The decrease in the preference for activity in the sphere of self-development related to the assumption regarding world's control is obviously connected with the youth's main goals being self-development and self-change, rather than changes in the surrounding reality. Perhaps, the belief regarding control of the world, which includes control over other people, does not contribute to a high evaluation of the significance of activity in the field of self- 
development, because young people do not see an ability to control the world, and thus confine themselves to self-change.

Students' preferences regarding recreational and cognitive activity have two positive predictors in terms of basic personal assumptions. They are the assumption regarding the benevolence of the world $(\beta=0.288)$ and the assumption regarding the possibility of self-control $(\beta=0.223)$. The belief that, on the whole, everything is going to be all right, and the people in one's environment are generally supportive, promotes a preference for social activity in the field of tourism and physical activity. Perhaps, this can be explained by the important role of these subject-personal qualities in the process of organizing one's life under difficult conditions, which requires self-control and trust in one's partners for interaction.

The assumption regarding the possibility of self-control is a positive predictor of a generalized preference for social activity $(\beta=0.156)$. This relationship indicates the orientation of young people toward the impact of realizing social activity on their own thoughts and actions, as well as the possibility of their self-regulation. On the one hand, this promotes the internality of young people in the process of social interaction; on the other hand, it complicates the possibility of influence, including pro-social influence, on partners in the social activity.

We have to point out that we found no predictor of preference regarding mass cultural and spiritual-religious social activity of students in terms of their basic individual beliefs.

\section{The Impact of Identity Characteristics}

Let us now turn to the results of regression analysis, where we evaluated which characteristics of identity became predictors of which form of social activity a student would choose (Table 2). As we can see from Table 2, recreational-cognitive, spiritual-religious, Internet-network, and political activities are most strongly conditioned by identity characteristics.

Students' preference for recreational and cognitive social activity has two predictors: the positive predictor is consciousness of their physical appearance $(\beta=0.147)$, and the negative predictor is their sense of personal identity $(\beta=-0.155)$. Positive prediction of the preference for recreation and cognitive social activity due to personal appearance is related to the fact that self-consciousness about one's appearance (eye color, hair color, height, body type, etc.) contributes to an assessment of one's physical (primarily strength-related) opportunities, which is important for the implementation of recreational and cognitive social activity (group tourism). The negative prediction of the preference for social activity in group tourism due to personal identity is related to the fact that a developed sense of personal identity helps one recognize oneself as a unique person who stands out in the social environment; such a trait is obviously not accepted in group tourism, which requires teamwork and group norms and values.

Preference for activity in the field of self-development is reduced if one's identity is based on one's relatives and family $(\beta=-0.193)$. Defining yourself as a family member and through you roles in interaction with relatives does not help you focus on your own development needs. On the contrary, identity based on relatives and family promotes a preference for Internet and network activity $(\beta=0.2)$, which in- 
Table 2

Identification categories as predictors of social activity

\begin{tabular}{|c|c|c|c|c|c|c|}
\hline \multirow{3}{*}{$\begin{array}{l}\text { Form of activity } \\
\begin{array}{l}\text { Recreational } \\
\text { and cognitive }\end{array}\end{array}$} & \multirow{3}{*}{\begin{tabular}{l}
\multicolumn{1}{c}{$\begin{array}{c}\text { Identification } \\
\text { categories }\end{array}$} \\
Personal identity \\
Physical identity \\
(appearance)
\end{tabular}} & \multicolumn{2}{|c|}{$\begin{array}{l}\text { Non-standardized } \\
\text { coefficients }\end{array}$} & \multirow{2}{*}{$\begin{array}{c}\begin{array}{c}\text { Standardized } \\
\text { coefficients }\end{array} \\
-0.155\end{array}$} & \multirow{2}{*}{$\begin{array}{c}\mathbf{t} \\
-2.168\end{array}$} & \multirow{2}{*}{$\begin{array}{c}\mathbf{p} \\
0.031\end{array}$} \\
\hline & & -0.881 & 0.406 & & & \\
\hline & & 1.153 & 0.561 & 0.147 & 2.056 & 0.041 \\
\hline \multicolumn{7}{|c|}{$\mathrm{R}^{2}=0.47 ; \mathrm{F}=4.595, \mathrm{p}<0.01$} \\
\hline $\begin{array}{l}\text { Activity in the } \\
\text { sphere of self- } \\
\text { development }\end{array}$ & $\begin{array}{l}\text { Relatives and } \\
\text { family }\end{array}$ & -1.005 & 0.374 & -0.193 & -2.686 & 0.008 \\
\hline \multicolumn{7}{|c|}{$\mathrm{R}^{2}=0.04 ; \mathrm{F}=7.21, \mathrm{p}<0.01$} \\
\hline $\begin{array}{l}\text { Hobby-related } \\
\text { and commu- } \\
\text { nicative social } \\
\text { activity }\end{array}$ & $\begin{array}{l}\text { Negative individual } \\
\text { identity }\end{array}$ & 0.601 & 0.259 & 0.167 & 2.317 & 0.022 \\
\hline \multicolumn{7}{|c|}{$\mathbf{R}^{2}=\mathbf{0 . 0 3} ; \mathbf{F}=5.37, \mathbf{p}<\mathbf{0 . 0 5}$} \\
\hline $\begin{array}{l}\text { Internet and } \\
\text { network activity }\end{array}$ & $\begin{array}{l}\text { Relatives and } \\
\text { family }\end{array}$ & 1.051 & 0.376 & 0.200 & 2.798 & 0.006 \\
\hline \multicolumn{7}{|c|}{$\mathbf{R}^{2}=\mathbf{0 . 4} ; \mathbf{F}=7.83, \mathbf{p}<\mathbf{0 . 0 1}$} \\
\hline \multirow{2}{*}{$\begin{array}{l}\text { Socio-political } \\
\text { activity }\end{array}$} & Ethnic identity & -1.264 & 0.443 & -0.202 & -2.853 & 0.005 \\
\hline & $\begin{array}{l}\text { Negative individual } \\
\text { identity }\end{array}$ & -0.992 & 0.415 & -0.169 & -2.392 & 0.018 \\
\hline \multicolumn{7}{|c|}{$\mathrm{R}^{2}=0.09 ; \mathrm{F}=5.73, \mathrm{p}<0.01$} \\
\hline \multirow{2}{*}{$\begin{array}{l}\text { Culture and } \\
\text { mass social } \\
\text { activity }\end{array}$} & Activist & 1.089 & 0.356 & 0.217 & 3.062 & 0.003 \\
\hline & Gender identity & 0.776 & 0.344 & 0.160 & 2.257 & 0.025 \\
\hline \multicolumn{7}{|c|}{$R^{2}=0.07 ; F=6.90 . p<0.001$} \\
\hline \multirow{3}{*}{$\begin{array}{l}\text { Social activity } \\
\text { in the spiritual } \\
\text { and religious } \\
\text { sphere }\end{array}$} & Religious identity & 4.113 & 0.589 & 0.455 & 6.981 & 0.000 \\
\hline & Ethnic identity & -0.890 & 0.315 & -0.184 & -2.828 & 0.005 \\
\hline & $\begin{array}{l}\text { Educational } \\
\text { identity }\end{array}$ & 0.822 & 0.294 & 0.180 & 2.793 & 0.006 \\
\hline \multicolumn{7}{|c|}{$\mathbf{R}^{2}=\mathbf{0 . 2 4} ; \mathbf{F}=19.39, \mathbf{p}<\mathbf{0 . 0 0 1}$} \\
\hline $\begin{array}{l}\text { Creative social } \\
\text { activity }\end{array}$ & Personal identity & 1.728 & 0.420 & 0.288 & 4.112 & .000 \\
\hline \multicolumn{7}{|c|}{$R^{2}=0.08 ; F=16.91, p<0.001$} \\
\hline $\begin{array}{l}\text { Volunteering } \\
\text { social identity }\end{array}$ & $\begin{array}{l}\text { Negative individual } \\
\text { identity }\end{array}$ & -0.825 & 0.318 & -0.186 & -2.590 & 0.010 \\
\hline \multicolumn{7}{|c|}{$\mathrm{R}^{2}=0.04 ; \mathrm{F}=6.71, \mathrm{p}<0.01$} \\
\hline
\end{tabular}


dicates, perhaps, the ease of realizing this type of social activity in the family, since it is possible to combine family roles and activity in the Internet space.

The positive predictor of students' preference for hobby-related and communicative social activity is a negative sense of personal identity $(\beta=0.167)$. Internal contradictions, lack of a clear image of oneself, and the inability to perceive one's own characteristics reduces preferences for friendly interactions, which may be due to low self-esteem and fear of criticism from others in close personal relationships.

Negative personal identity $(\beta=-0.169)$ also reduces the preference for social and political activity, where implementation of opposite traits is obviously important. Among them are a positive image of oneself, high self-esteem, awareness of one's own characteristics, and identity of time and situation. Preference for social and political activity is also reduced under the influence of ethnic identity $(\beta=-0.202)$. Obviously, students understand that in order to carry out social and political activity, first and foremost, they need a civic identity, and that an ethnic identity will not contribute to solving the problems of the country as a whole.

The predictors of the preference for mass cultural social activity are very specific. They are awareness of one's qualities, promoting the activity $(\beta=0.217)$, and gender identity $(\beta=0.16)$. In the first case, the awareness of one's activity and the qualities that contribute to this activity is the necessary condition for the relatively energy-consuming aspects of mass culture social activity. In the second case, one's identification with a group of one's gender actualizes needs specific to members of a certain sex, which, obviously, can be satisfied in this kind of social activity.

Regarding the diverse prediction of students' preferences for social activity in the spiritual and religious sphere, we can point to two positive predictors, i.e. religious $(\beta=0.455)$ and educational identity $(\beta=0.18)$, and one negative predictor, i.e. ethnic identity $(\beta=-0.184)$. The fact that religious identity is a predictor of students' preference for social activity in the spiritual and religious sphere is quite understandable, because of the importance of this sphere for a believer, and the need to realize his/her place in his/her faith. Educational identity enhances this type of social activity, perhaps because of the recognition of the student's role not only in the sphere of secular education, but also in his/her relations with the clergy. The overwhelming role of students' ethnic identity in decreasing the preference for social activity in the spiritual and religious sphere testifies to the multi-directionality and different content of the formation of religious and ethnic feelings, as well as the processes of referring oneself to a certain group, either by the criterion of faith or by the criterion of ethnos.

The positive predictor of preferences for creative social activity is personal identity $(\beta=0.288)$, since perceiving oneself as a complete personality with awareness of one's specific abilities and potential, influences the choice and intensity of creative activity, increases the likelihood of its high-quality performance, and helps one to get satisfaction and confirm one's own identity.

Volunteer social activity has one negative predictor, i.e., negative personal identity $(\beta=-0.186)$. With negative personal identity, preference for volunteer social activity in the form of volunteerism and selfless help to those in need is reduced, because intrapersonal problems expressed through low self-esteem, negative selfconcept, and the inability to form a holistic positive image of oneself, capture the individual and make it difficult for him/her to focus on the problems of other people. 


\section{Discussion}

Classification of the directionality of young people's activity, compiled via cluster analysis, made it possible to identify single-order groups of social activity. Various levels of cluster complexity allowed us to show that students' preference for individual and personal forms of social activity is related to the breadth of their various spheres of activity and the activities' complementarity. It also allowed us to understand the possible intensity of individual and personal activity in comparison with organizational and social activity. One can see the relative independence of preference for organizational social activity and individual-personal social activity, which may be due to different levels of accessibility, or to the fact that these two forms of social activity allow satisfying different altruistic and individual needs. This data is consistent with the results of research on the notions of preferred spheres of social activity in Russia (Kuprejchenko \& Moiseev, 2010; Serdjuk, 2015; Sitarov \& Maralov, 2015), which established not only the significance of spheres of activity, but the proximity and remoteness of various forms of activity.

Regression analysis allowed us to come to conclusions regarding some patterns of determination concerning young people's preferences for certain types of social activity from the point of view of their basic beliefs and identities.

The strongest predictors of social activity among young people are beliefs in their own values, in their ability to control the events, and in their luckiness. These and other beliefs accounted for up to $22 \%$ of the variations in activity in the field of education; up to $12 \%$ of variations in recreational and cognitive activity; and $9 \%$ of the variations in activity in the sphere of personal self-development. Characteristics of identity accounted for up to $47 \%$ of the variations in recreational and cognitive activity of young people; $24 \%$ of the variations in preferences of activity in the spiritual and religious sphere; and $9 \%$ of the variations in preferences for socio-political activity.

Meanwhile, a number of studies have shown some relationship between young people's notions of the world, and their actions or behavior. This research makes it possible to establish that people "rewrite" reality around their favorable course of action, going beyond the logic of their own preferences (Herrmann, 2017). Assumptions about the world and other people regulate young people's social behavior according to the needs of their community or their own needs (Maes et al., 2012, Shamionov et al., 2014; Shamionov, 2019). This data indicates the significant prognostic power of these phenomena, and that the share of explanatory variance of other personal characteristics or situational factors may also be significant. The study of these phenomena is the goal of our follow-up research.

The lack of predictors of students' preference for mass cultural and spiritualreligious social activity from the point of view of their individual basic beliefs is explained by the fact that, in the first case, this prediction has no functional significance. In the second case, the significance of spiritual and religious activity is obviously not determined by beliefs related to the evaluation of the world and one's impact on it; it is determined by beliefs about the existence of influence of external higher forces on the world.

Regression analysis made it possible for us to identify the characteristics of identity which are the most influential predictors of young people's preference for 
various types of social activity. Among these predictors we can single out negative individual, personal, and family and relative-related identity. To a lesser extent, the preference for social activity types is influenced by sexual, religious, and ethnic identity, as well as a sense of identity based on activity and appearance. Our study has revealed a diverse prediction of students' preference for social activity in the spiritual and religious sphere, while other types of social activity are conditioned by fewer predictors.

In general, as it follows from the results of regression analysis, the level of predictability of different forms of social activity varies significantly. Assumptions about the world and one's own identity make different contributions to preferences for certain forms of social activity. While sense of identity mainly determines variations of the first cluster (political, religious and voluntary), assumptions about the world predominantly condition the second cluster (from educational up to recreational and cognitive activity). These results testify to the fact that different forms of social activity can be conditioned by different personal instances, i.e. ideas about the world and about oneself.

\section{Conclusion}

Analysis of the study results brings us to the following conclusions:

1. All forms of students' social activity can be grouped into two clusters. The less complex cluster is called "significance of organizational and social forms of social activity," which combines less significant forms of social activity. The more complex cluster is called "significance of individual and personal forms of social activity", which includes the "significance of social activity for self-development "and the "significance of social activity in the sphere of entertainment." Each of these in turn includes individual sub-clusters related to personal and physical selfdevelopment and product and consumer-related entertainment.

2. Different levels of cluster complexity made it possible to conclude that the significance of individual and personal forms of social activity for young people is related to the breadth of their various spheres of activity and their complementarity. It also allowed us to judge the possible intensity of individual and personal activity compared to organizational social activity.

3. Regression analysis resulted in our establishing which assumptions make the most significant contribution to variations in social activity preferences. The most complex prediction regarding the importance of educational and developmental activity of students is connected with direct influence of assumptions regarding justice of the world and self-worth, and the reverse influence of the assumption regarding luckiness and control of the world. There is no influence of personal basic assumptions on the assessment of significance of cultural, religious, creative, and informal activity in the student group. The importance of the Internet, network, and volunteer activity only had negative predictive power from the point of view of basic individual beliefs. Hobby-related, communicative, recreational, and cognitive activity, as well as the students' general assessment of the importance of social activity, could only be positively predicted if the students had a basic individual belief in the possibility of self-control and a positive assumption regarding the benevolence of the world. 
4. A student's sense of identity influences what type of social activity he or she prefers. The most influential predictors of social activity preferences are negative personal, personal, and family and relative-related identities. To a lesser extent, preference for the type of social activity is influenced by sexual, religious, and ethnic identity, as well as identity based on activity and appearance. Our study revealed diverse predictors of the preference for social activity in the spiritual and religious sphere; the remaining types of social activity were conditioned by a smaller number of predictors. Negative personal identity causes a decrease in the preference for organizational and social forms of social activity, which can be explained by the focus of the individual's attention on his/her own problems.

The significance of this study lies in the possibility of explaining the causes and determinants of social activity as an effect of young people's socialization. Vagueness about the reasons for social activity and its determinants can lead to an unjustified restriction of activity, which will contribute to the social regress.

The results of this study can be used in the development of programs for the harmonization of social relations by supporting youth initiatives aimed at attracting young people to innovative civic, voluntary, and political activity.

\section{Acknowledgements}

This research was funded by a grant from the Russian Science Foundation (project No. 18-18-00298).

\section{References}

Abul'khanova-Slavskaya, K.A. (1999). Psikhologiya i soznanie lichnosti (problemy metodologii, teorii i issledovaniya real'noi lichnosti). [Psychology and consciousness of the person (problems of methodology, theory and research of the real person)]. Moscow: Moskovskii psikhologo-sotsial'nyi institut; Voronezh: NPO "MODEK".

Akbarova, A.A. (2015). Sotsial'naya aktivnost' kak element sotsial'nogo samoopredeleniya molodezhi [Social activity as an element of social self-determination of youth]. Izvestiya of Saratov University. New Series. Series: Educational Acmeology. Developmental Psychology, 4(1), 41-45.

Ang, R.P., Li, X., \& Seah, S.L. (2017). The Role of Normative Beliefs About Aggression in the Relationship Between Empathy and Cyberbullying. Journal of cross-cultural psychology, 48(8), 1138-1152. https://doi.org/10.1177/0022022116678928

Balabanova, E.S. (2017) Razvitie predstavlenii o sotsial'noi aktivnosti molodezhi v otechestvennykh sotsial'no-psikhologicheskikh issledovaniyakh [Development of ideas about youth civic engagement in national socio-psychological research]. Chelovecheskii faktor: problemy psikhologii i ergonomiki [Human Factors: Problems of Psychology and Ergonomics], 1(81), 48-54.

Belyaeva, D.E., \& Istratova, O.N. (2014). Proyavlenie poznavatel'noi aktivnosti u sotsial'nykh sirot mladshego shkol'nogo vozrasta [Manifestation of cognitive activity in social orphans of primary school age]. Fundamental'nye i prikladnye issledovaniya $v$ sovremennom mire, $3(8), 114-117$.

Catlin, G., \& Epstein, S. (1992). Unforgettable experiences: The relation of life events to basic beliefs about self and world. Social cognition, 10(2), 189-209. https://doi.org/10.1521/soco.1992.10.2.189 
Chan, M., \& Guo, J. (2013). The Role of Political Efficacy on the Relationship Between Facebook Use and Participatory Behaviors: A Comparative Study of Young American and Chinese Adults. Cyberpsychology behavior and social networking, 16(6), 460-463. https://doi.org/10.1089/cyber.2012.0468

Dzhioeva, O.F. (2015). Sotsial'naya aktivnost' kak faktor sotsializatsii lichnosti [Social activity as a factor of personality socialization]. $V$ mire nauchnykh otkrytii [Siberian Journal of Life Sciences and Agriculture], 7.1, 483-493. Retrieved from http://journal-s.org/index.php/vmno/article/view/6403

Eremina, L.I. (2015). Sootnoshenie kreativnosti i sotsial'noi aktivnosti studentov v sotsial'nopreobrazuyushchei deyatel'nosti [The value of creativity and social activity of students in socially transformative activity]. Izvestiya of Saratov University. New Series. Series: Educational Acmeology. Developmental Psychology, 4(2), 155-159.

Federal State Statistics Service (Rosstat) (2018). Education. http://www.gks.ru/wps/wcm/connect/rosstat_main/rosstat/en/figures/education/

Ferguson, R., Gutberg, J., Schattke, K., Paulin, M., \& Jost, N. (2015). Self-determination theory, social media and charitable causes: An in-depth analysis of autonomous motivation. European journal of social psychology, 45(3), 298-307. https://doi.org/10.1002/ejsp.2038

Furman, Ju. V., \& Gridina, O.N. (2015). Sotsial'naya aktivnost' - osnova resheniya problem molodezhi sel'skoi mestnosti [Social activity is the basis of solving the problems of rural youth]. Baikal Research Journal, 6(6), 16, https://doi.org/10.17150/2411-6262.2015.6(6).16

Grant, P.R, Bennett, M., \& Abrams, D. (2017). Using the SIRDE model of social change to examine the vote of Scottish teenagers in the 2014 independence referendum. British journal of social psychology, 56(3), 455-474. https://doi.org/10.1111/bjso.12186

Grigoryev, A.V. (2014). Lichnostnye kachestva i kharakteristiki otnoshenii k aktivnosti kak prediktory sotsial'no-psikhologicheskoi adaptatsii lichnosti $\mathrm{v}$ zavisimosti ot napravlenii realizuemoi aktivnosti [Personal qualities and characteristics of relations to activity as predictors of social and psychological adaptation of personality depending on directions of realized activity] Sovremennye problemy nauki i obrazovaniya, 3(3), 630. Retrieved from https://www.science-education.ru/ru/article/view?id=14546

Grigoryeva, M.V. (2012). Urovnevyi analiz faktorov sotsial'noi aktivnosti molodezhi [Level analysis of social activity factors of youth. People in economic and social relations]. Chelovek v ekonomicheskikh i sotsial'nykh otnosheniyakh. Moscow: NOU VPO Institute of world economy and Informatization, 43-45.

Grigoryeva, M.V. (2018) Evaluation of young people's social activity by representatives of other generations / ICERI2018 Proceedings, 11th International Conference of Education, Research and Innovation November 12th-14th/. Seville, Spain, 7491-7495. https://doi.org/10.21125/iceri.2018.0338

Hardy, S.A., Dollahite, D.C., Johnson, N., \& Christensen, J.B. (2015). Adolescent Motivations to Engage in Pro-Social Behaviors and Abstain from Health-Risk Behaviors: A Self-Determination Theory Approach. Journal of personality, 83(5), 479-490. https://doi.org/10.1111/jopy.12123

Herrmann, R.K. (2017). How Attachments to the Nation Shape Beliefs About the World: A Theory of Motivated Reasoning. International organization, 71(1), S61-S84. https://doi.org/10.1017/S0020818316000382

Janoff-Bulman, R. (1989). Assumptive Worlds and the Stress of Traumatic Events: Applications of the Schema Construct. Social Cognition, 7, Special Issue: Stress, Coping, and Social Cognition, 113-136. https://doi.org/10.1521/soco.1989.7.2.113

Janoff-Bulman, R. (1992). Shattered Assumptions: Towards a New Psychology of Trauma. New York: Free Press. 
Kalaitzaki, A. \& Wright, M.F. (2017). Cyberstalking Victimization and Perpetration among Greek College Students. Identity, sexuality, and relationships among emerging adults in the digital age (Advances in Human and Social Aspects of Technology). 247-261. https://doi.org/10.4018/978-1-5225-1856-3.ch015

Kiseljova, T.G. (2014). Refleksivno-aksiologicheskii podkhod $\mathrm{k}$ formirovaniyu sotsial'noi odarennosti i sotsial'noi aktivnosti podrostkov i molodezhi [A Reflexive-axiological approach to the formation of social endowments and social activity of adolescents and youth]. Vestnik of Kostroma state University. N. Nekrasov. Series: Pedagogics. Psychology. Social work. Juvenile. Sociokinetic, 20(2), 136-141.

Kondrateva, E.V. (2017). Formirovanie sotsial'noi aktivnosti v studencheskom vozraste [Formation of social activity of student's age]. Otechestvennyi zhurnal sotsial'noi raboty [Russian journal of social work], 4, 114-118.

Koo, H.J., Woo, S., Yang, E., and Kwon, J.H. (2015). The Double Meaning of Online Social Space: Three-Way Interactions Among Social Anxiety, Online Social Behavior, and Offline Social Behavior. Cyberpsychology behavior and social networking, 18(9), 514-520. https://doi.org/10.1089/cyber.2014.0396

Kravcova, O.A. (2000). Sexual violence as a psychological trauma. PhD dissertation. Moscow.

Krasilshhikov, V.V., \& Osetrov, M.A. (2017). Analiz aktivnosti studentov v sotsial'noi seti [Analysis of student activity in social networks]. Vysshee obrazovanie $v$ Rossii [Higher Education in Russia], 2, 52-62.

Kudinov, S.S. (2014). Sotsial'naya aktivnost' kak osnova samorealizatsii lichnosti [Social activity as the basis of self-identity]. Akmeologiya, 1-2, 124-125.

Kuprejchenko, A.B., \& Moiseev, A.S. (2010). Analiz znachimosti sfer zhizni i napravlenii zhiznedeyatel'nosti predstavitelei sovremennogo gorodskogo srednego klassa [Analysis of the significance of life spheres and directions of activity of the representatives of contemporary urban middle-class]. Znanie. Ponimanie. Umenie [Knowledge. Understanding. Skill], 4, 204-209.

Maes, J., Tarnai, C., \& Schuster, J. (2012). About Is and Ought in Research on Belief in a Just World: The Janus-Faced Just-World Motivation. In Elisabeth Kals \& Jürgen Maes (Ed.), Justice and conflicts. Theoretical and empirical contributions (pp. 93-106). Springer. https://doi.org/10.1007/978-3-642-19035-3_5

Merrilees, C.E., Cairns, Ed, Taylor, L.K, Goeke-Morey, M.C., Shirlow, P., \& Cummings, E.M. (2013). Social Identity and Youth Aggressive and Delinquent Behaviors in a Context of Political Violence. Political psychology, 34(5), 695-711. https://doi.org/10.1111/pops.12030

Miller, S.R. (2012). I don't want to get involved: Shyness, psychological control, and youth activities. Journal of social and personal relationships, 29(7), 908-929. https://doi.org/10.1177/0265407512448266

Moiseev, A.S. (2013). Psikhologicheskie tipy sotsial'nogo samoopredeleniya predstavitelei srednego klassa moskovskogo regiona [Psychological types of social self-determination of representatives of the middle class of the Moscow region]. Znanie. Ponimanie. Umenie [Knowledge. Understanding. Skill], 1. Retrieved from http://www.zpu-journal.ru/e-zpu/2013/1/Moiseev_Social-Self-determination-Middle-Class

Padun, M.A., \& Kotelnikova, A.V. (2012). Psihologicheskaya travma I kartina mira [Psychological trauma and world view]. Moscow: Izd-vo Institut psihologii RAS.

Pegg, K.J., O’Donnell, A.W., Lala, G., \& Barber, B.L. (2018). The Role of Online Social Identity in the Relationship Between Alcohol-Related Content on Social Networking Sites and Adolescent Alcohol Use. Cyberpsychology behavior and social networking, 21(1), 50-55. https://doi.org/10.1089/cyber.2016.0665 
Pekushkina, D.V. (2016). Proektnaya deyatel'nost' kak sredstvo formirovaniya sotsial'noi aktivnosti studentov [Project activities as a means of formation of social activity of students]. Chelovecheskii kapital [Human capital], 11(95), 22-24.

Perminova, M.S. (2016). Spetsifika formirovaniya sotsial'noi aktivnosti molodezhi v usloviyakh volonterskoi deyatel'nosti [Specificity of formation of social Activity of Young People in Volunteer Activities]. Izvestiya of Saratov University. New Series. Series: Sociology. Politology, 16(1), 22-25. htpp://doi.org/10.18500/1818-9601-2016-16-1-22-25

Rjabikina, Z.I., \& Bogomolova, E.I. (2015). Vzaimosvyaz' lichnostnykh kharakteristik pol'zovatelei sotsial'nykh setei interneta s osobennostyami ikh aktivnosti v seti [Interrelation of personal characteristics of users of social networks of the Internet with features of their activity in the network]. Politematicheskii setevoi elektronnyi nauchnyi zhurnal Kubanskogo gosudarstvennogo agrarnogo universiteta, 109, 1041-1057. Retrieved from http://ej.kubagro.ru/2015/05/pdf/73.pdf

Rozhkova, A.V. (2015). Otnoshenie k tsennostnykh normativam grazhdanskoi sfery v zavisimosti ot urovnya i soderzhaniya sotsial'noi aktivnosti studentov [Attitude to the value standards of the civil sphere, depending on the level and content of social activity of students]. Mir obrazovaniya - obrazovanie v mire [world of education-education in the world], 4, 234-240.

Rudneva, N.V. (2017). Tekhnologiya stimulirovaniya sotsial'noi aktivnosti pri formirovanii pravovoi kul'tury studentov vuza [Technology stimulate social activity in the formation of legal culture of students of the University]. Pravo i obrazovanie, 2, 58-64. https://doi.org/10.24158/spp.2017.8.24

Russo, S., \& Amna, E. (2016). When political talk translates into political action: The role of personality traits. Personality and individual differences, 100, 126-130. https://doi.org/10.1016/j.paid.2015.12.009

Savrasova-V'un, T. (2017). Social networks and their role in development of civic activity of the Ukrainian youth. Communication today, 8(1), 104-112.

Sedova, M.I. (2015). Sotsial'naya aktivnost' starsheklassnikov i ee razvitie v usloviyakh v usloviyakh malogo goroda [Social activity of high school students and its development in conditions in a small town]. Uchenye zapiski Rossiiskogo gosudarstvennogo sotsial'nogo universiteta [Scientific notes of the Russian state social University], 5(132), 131-139.

Seigfried-Spellar, K.C., \& Lankford, C.M. (2018). Personality and online environment factors differ for posters, trolls, lurkers, and confessors on Yik Yak. Personality and individual differences, 124, 54-56. https://doi.org/10.1016/j.paid.2017.11.047

Serdjuk, E.N. (2015). Sotsial'naya aktivnost' lichnosti i formy ee proyavleniya [Social activity of a person and forms of its manifestation]. Nauchnyi al'manakh [Scientific almanac], 4(6), 173-176.

Shamionov, R.M. (2012). Psikhologicheskie kharakteristiki sotsial'noi aktivnosti lichnosti [Psychological characteristics of social activity of the person]. Mir psikhologii [World of psychology], 3, 145-154.

Shamionov, R.M. (2017). Otnoshenie k izmeneniyam i tolerantost' k neopredelennosti kak prediktory adaptivnosti i adaptatsionnoi gotovnosti [Attitude to change and tolerance to uncertainty as predictors of adaptability and adaptive readiness]. Russian psychological journal, 14(2), 90-104. https://doi.org/10.21702/rpj.2017.2.5

Shamionov, R.M. (2019). Socio-psychological factors of preferences regarding the socio-economic and socio-political activity of Russian provincial youth. Helix, 9(1), 4813-4817. https://doi.org/10.29042/2019-4813-4817 
Shamionov, R.M., \& Grigoryeva, M.V. (2012). Psikhologiya sotsial'noi aktivnosti molodezhi: problemy i riski [Psychology of social activity of youth: problems and risks]. Saratov: Izdatel'stvo Saratovskogo universiteta.

Shamionov, R.M., Grigoryeva, M.V., \& Grigoryev, A.V. (2014). Influence of beliefs and motivation on social-psychological adaptation among university students. Proceeding Social and Behavioral Sciences, 112, 323-332. https://doi.org/10.1016/j.sbspro.2014.01.1171

Sharkovskaja, N.V. (2016). Sotsial'no-kul'turnaya aktivnost' - ponyatie sovremennoi sotsial'nokul'turnoi deyatel'nosti [Socio-cultural activity - the concept of modern socio-cultural activities]. Vestnik of the Moscow state University of culture and arts, 3(71), 116-121.

Sherman, L.E., Greenfield, P.M., Hernandez, L.M., \& Dapretto, M. (2018). Influence Via Instagram: Effects on Brain and Behavior in Adolescence and Young Adulthood. Child development, 89(1), 37-47. https://doi.org/10.1111/cdev.12838

Shhebetenko, S.A. (2016). Ustanovki na cherty lichnosti kak prediktor aktivnosti «druzei» pol'zovatelya sotsial'noi seti «V kontakte» [Attitudes to personality traits as a predictor of the activity of "friends" of the user of the social network "in contact"]. Natsionalny Psikhologichesky Zhurnal [National psychological journal], 4(24), 34-44. https://doi.org/10.11621/npj.2016.0404

Sitarov, V.A., \& Maralov, V.G. (2015). Sotsial'naya aktivnost' lichnosti (urovni, kriterii, tipy, i puti ee razvitiya) [Social activity of the individual (levels, criteria, types, and ways of its development)]. Znanie. Ponimanie. Umenie, 4, 164-176. https://doi.org/10.17805/zpu.2015.4.15

Skornjakova, Je.R. (2015). Sotsial'naya aktivnost' uchashchikhsya v ramkakh deyatel'nosti detskikh obshchestvennykh ob"edinenii [Social activity of schoolchild in the activity of children's public associations]. Problemy i perspektivy razvitiya obrazovaniya $v$ Rossii, 35, 113-117.

Solobutina, M.M., \& Nesterova, M. (2018) Motivation of Voluntary Activity and Personal World Assumptions of the Youth. Helix, 8(1), 2397-2401. https://doi.org/10.29042/2018-2397-2401

Yushchenko. I.N., \& Fatyhova, R.M. (2016). Psikhologicheskie determinanty sotsial'noi aktivnosti lichnosti studentov pedagogicheskogo vuza [Psychological determinants of social activity of students of pedagogical higher education institutions]. Vestnik Bashkirskogo gosudarstvennogo pedagogicheskogo universiteta im. M. Akmully [Bulletin of Bashkir state pedagogical University. M. Akmully], 1(37), 29-37.

Original manuscript received July 26, 2018

Revised manuscript accepted March 04, 2019

First published online June 15, 2019

To cite this article: Shamionov, R.M., Grigoryeva, M.V., Grigoryev, A.V. (2019). World Assumptions and Youth Identity as Predictors of Social Activity Preferences. Psychology in Russia: State of the Art, 12(2), 115-133. DOI: 10.11621/pir.2019.0209 